\title{
Tale of Fish Sperm and Factors Affecting Sperm Motility: A Review
}

\author{
M. Sadiqul Islam*, T. Akhter \\ Department of Fisheries Biology \& Genetics, Bangladesh Agricultural University, Mymensingh, 2202, Bangladesh
}

\begin{abstract}
Motility is an important function of the male gamete, which allows sperm to actively reach and penetrate the female gamete in organisms with internal and external fertilization. Sexual activity of some fish is generally seasonal and fertilization is external. Sperm, once differentiated in the gonad, remain there completely quiescent until they are released into the external medium, which is either freshwater or sea water. Various parameters such as ion concentrations $\left(\mathrm{K}^{+}, \mathrm{Na}^{+}\right.$, $\mathrm{Ca}^{2+}$ ), osmotic pressure, $\mathrm{pH}$, and temperature affect motility. In the present paper, we review the roles of these factors on sperm motility in the teleosts. Studying the effects of these factors on teleost sperm can help establish good activation and/or immobilizing media for improving either artificial fertilization or cryopreservation.
\end{abstract}

Keywords Fish, Sperm, Motility, Ion, Osmotic Pressure

\section{Introduction}

Fish sperm are widely divergent in form and structure[1] It is not possible to construct a spermatic model for the 'fishes', as is the case, for example for the snakes and mammals. They vary from aflagellate to biflagellate and have an enormous range of shapes, sizes, and structures; the number and location of organelles also vary[2, 3, 4]. Both light and electron microscopy of a wide spectrum of teleost sperm have demonstrated that important morphological differences can be found among species[5] and can be used for taxonomic purposes[2]. The structure of the spermatozoon is influenced by both reproductive mode and systematic position[6]. For example, the conclusion of Mattei and Mattei[7] based on the study of sperm of eight species of fishes from the orders Elopiformes and Anguilliformes supported the theory of other workers that these two orders should be grouped together in the super order Elopomorpha. Morphological differences in teleost spermatozoa indicate that submicroscopical morphology of these cells can be useful as additional characters in taxonomic classification as suggested by many researchers $[2,7,8]$.

Study of the structure and morphology of fish sperm provides information for understanding their possible taxonomic and evolutionary relationships at family $[1,9]$, subfamily and species[10] levels, as well as for optimizing artificial reproduction, prevention of polyspermy problems and development of cryopreservation techniques[5]. Spermiogen

* Corresponding author:

sadiqu11973@yahoo.com (M. S. Islam)

Published online at http://journal.sapub.org/als

Copyright (C) 2011 Scientific \& Academic Publishing. All Rights Reserved -esis and spermatozoon ultra-structure has been studied in a number of teleost fishes with those variations having phylogenetic importance reported $[1,11,12]$.

Most of the externally fertilizing teleosts cannot swim in the male gonads. Sperm are only become motile and metabolically active after release into the water. Within the gonad, high $\mathrm{CO}_{2}$ tension in semen maintains intracellular $\mathrm{pH}$ at $\sim 7.2$ with respect to sea water[13]. When sperm are spawned into seawater, the $\mathrm{CO}_{2}$ concentration decreases, $\mathrm{H}^{+}$ release and intracellular $\mathrm{pH}$ increases to 7.5-7.6. Dynein, the ATPase that drives the flagella, is inactive below $\mathrm{pH} 7.3$, repressing motility and respiration[14, 15]. In most freshwater species, sperm usually moves for less than $2 \mathrm{~min}$ and in many cases is only highly active for less than $30 \mathrm{sec}[16,17$, $18,19]$. Some fish species such as the spotted wolfish (Anarhichas minor) and the 3- and the 15-spined sticklebacks (Gasterrosteus aculeatus, and Spinachia spinachia respectively), which are characterized by release of eggs in a sticky gelatinous mass, have sperm which remains motile for a far longer period after release[20, 21, 22]. In a recent finding it was found that Perca fluviatilis (perch) sperm have the ability to swim for more than two hours in saline conditions[23].

Sperm motility is the functional parameter that might be influenced directly and most significantly by sperm morphology and structure of sperm. Differences are observed in many species of teleosts in terms of length of the flagellum, number of mitochondria of the sperm which all can affect motility[2, 24]. In some species, the longest sperm swim fastest at high energy costs[25]. In an experiment it was found that perhaps longer sperm had more ATP available for swimming and achieved a higher fertilization success[26] and even sperm with higher velocities of sperm is able to 
fertilize a greater number of eggs[27]. Earlier it was mentioned that fish sperm remain quiescent in the genital tract and in the seminal plasma and they become transiently motile at spawning when released into the surrounding water. There are several factors that affect sperm motility such as $\mathrm{pH}$, temperature, ions and osmolality[28, 29, 30] which lead to activation of axonemal movement.

The aim of the present review is to discuss the structure and morphology of fish sperm and to discuss the effects of physical factors (e.g. temperature) and chemical factors (e.g. $\mathrm{pH}$, ions, osmotic pressure) that affect the motility of fish sperm.

\section{Methodology}

An extensive search of PUBMED, ScienceDirect and the author's files was done without limitations by language or species for citations relevant to fish sperm. Wider searches of citations relevant to morphology, physiology and signal transduction were also performed without limitations of language, species, or date, to broaden the background to this review. All papers that matched the search criteria and were relevant to this review were included. Diagrams were made using power point, collating data from references within the review and the table was generated in excel, by the same means.

\section{Morphology and Composition of Fish Sperm}

\subsection{Anatomy}

Sperm are quite small cells and display similar general design in almost all species (Figure 1). It consists of head, mid-piece and flagellum.

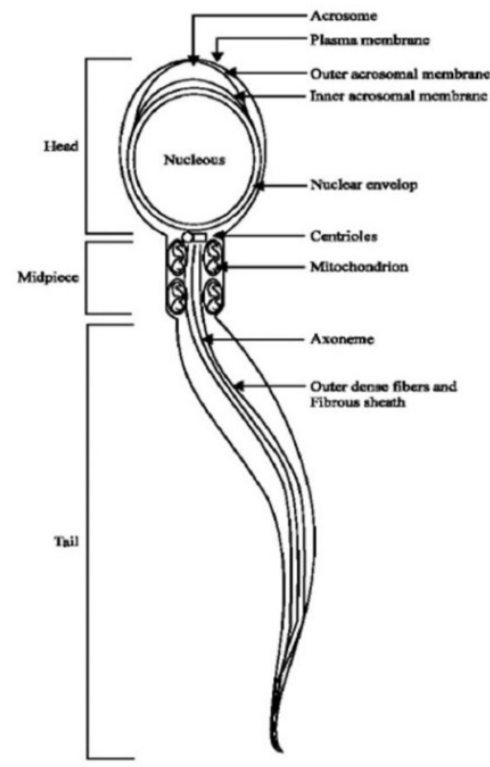

(a)

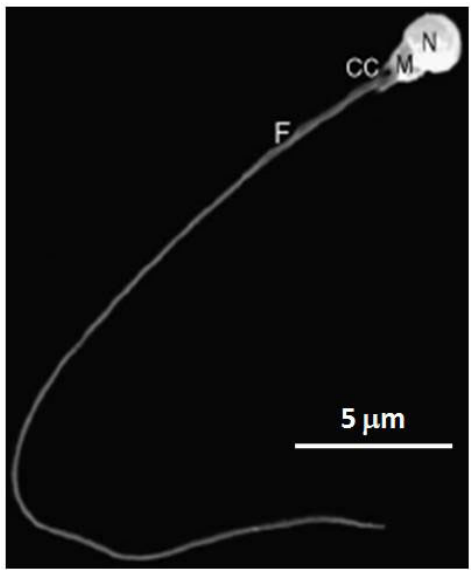

(b)

Figure 1. (a) Schematic model of a sperm consisting head, mid-piece and tail[112], (b) Scanning electron micrograph: sperm cell of Tench (Tinca tinca) with main structures is mentioned[113]. Nucleus (N), midpiece (M), flagellum (F) and cytoplasmic channel (CC). Scale bar $=5 \mu \mathrm{m}$.

\subsection{Head}

A head varying in diameter, containing condensed packages of chromosome in the nucleus (which occupies a significant portion of the head) and in some species the acrosome, a membranous structure overlying the nucleus in the anterior part of the sperm head (Figure 1). A proper size and shape of spermatozoon head is a prerequisite for the entering of spermatozoon throughout the micropyle[5]. Generally, the sperm head in fishes is relatively small $(2-4 \mu \mathrm{m})$ in relation to the total size of sperm. The exceptions were observed at Atlantic eel sperm[5, 31] and at sturgeons and paddlefish Polyodon spathula (Walbaum) with elongated sperm head up to $10 \mu \mathrm{m}$ in length and over $2 \mu \mathrm{m}$ in width, containing acrosome [5, 31, 32, 33, 34, 35, 36, 37] or acrosome less[38].

Different shapes of sperm head occur in chondrostean and teleostean fishes. For example, in northern pike Esox lucius Lit is regular, ball shaped[39, 40]; big sperm head in silver carp Hypophtalmichthys molitrix V.[41, 42]; ovoid in cardinal fish Apogon imberbis L.[43]; ornate in wrasse Thalassoma pavo L.; kidney-like in damselfish Chromis chromis L.; spherical in Mediterranean rainbow wrasse $\mathrm{Co}$ ris julis L.[8]; banana-shaped in Atlantic eel Anguilla anguilla L.[44, 45]; highly elongated in Mimagoniates barberi (Regan)[46]; crescent-shaped in Conger myriaster (Berewoort)[47]. In some species (e.g. in perch, Perca fluviatilis L.), the sperm head is laterally flattened[48].

\subsection{Mid-piece}

Mid-piece consists of centriole and mitochondria and linked with head (Figure 1). Mitochondria contains at the base of the tail, contributing to power flagellar movement. The midpiece is similar to that of a mammalian sperm, except for the fact that fish sperm contain fewer mitochondria and its flagellum is separated from the midpiece by a cytoplasmic channel[43]. In perch $P$. fluviatilis, only a single mitochondrion was found in the sperm head[48] while more than 20 mitochondria were found in the midpiece of ide Idus melanotus L.[5] and in cyprinids it varied from 2 to 10 [2]. 
In chondrostean and teleostean fishes, only the mitochondrial segment was found recognizable, while centriolar segment was hidden in so-called intranuclear channel[5]. In rainbow trout Oncorhischus mykiss (Walbaum), the distal centriole attached to the transverse axis system includes a free portion nesting on the proximal centriole, which varies in form between a circle and an ellipse. Same size of the both centrioles (30 nm length, $22 \mathrm{~nm}$ diameter) are arranged rectangularly to the head base in a roughly cubical depression equivalent to an implantation groove[49].

\subsection{Flagellum}

As the tails of sperm, flagella comprise the motile apparatus necessary to the movement and penetration of sperm into the egg at fertilization. The flagellum which varies in length, depending on the species and contains the axoneme (Figure 1). The length of flagellum in coho salmon $(O$. kisutch) is about $2.6 \mu \mathrm{m}$ [50], in channel catfish it is about 94 $\mu \mathrm{m}[51]$ and in C. myriaster it is $37 \mu \mathrm{m}$ in length[47]. Flagellar length in cyprinid species varies from 36 to $60 \mu \mathrm{m}$ [2]. The flagellum itself is composed from two central and nine peripheral doublet microtubules, so-called " $9+2$ complex"'[41] (Figure 2). The 9+2 structure and molecular composition of the axoneme are well conserved among eukaryotic cilia and flagella from protozoa to human. The nine doublet microtubules are interconnected and the central pair bridge joins the inner microtubules. This characteristic composition, i.e. $9+2$ structure with the central microtubules showing identical orientation were present in channel catfish Ictalurus punctatus (Rafinesque), coho salmon Oncorhynchus kisutch (Walbaum), common carp Cyprinus carpio L., loach Misgurnus fossilis L., Siniperca (Siniperca chuatsi, Siniperca kneri, and Siniperca scherzeri) [5, 12, 41, 50, 51] while in Anguilliformes and Elopiformes present a " $9+0$ ", structure without central microtubules[7]. Some peculiarities in the flagellum were reported for some species: cells with two flagella were found in plainfin midshipman Porichtis notatus (Girard)[52] and channel catfish I. punctatus[51].

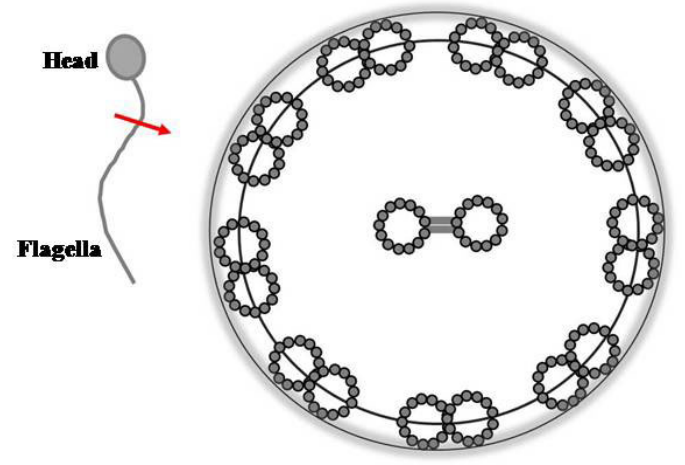

Figure 2. Schematic representation of the cross section of fish sperm flagellum showing the structure of axoneme. Axonemes are constructed from nine doublet microtubules and two singlet microtubules as shown by gray rings. The singlet microtubules at the center are joined by the central pair bridge. Nine doublet microtubules are connected with each other by interdoublet links and are surrounded by plasma membrane.

\section{Ionic Composition of Fish Milt}

Milt is defined as sperm plus seminal plasma. Seminal plasma (or fluid) has a unique composition: some components support the sperm, while others reflect the functions of the reproductive system and the sperm[53]. Studies on semen characteristics are necessary to understand the basic biochemical processes that occur in sperm motility and during fertilization $[54,55,56,57,58,59]$, to evaluate the reproductive abilities of different fish species[25, 55, 60, 61, $62]$, and to improve methods for short- and long-term storage of fish milt[63]. The ionic compositions of fish milt in different groups of fishes are summarized in Table 1.

Table 1. Ionic composition of the sperm and seminal plasma of different groups of fishes

\begin{tabular}{|c|c|c|c|c|c|c|c|}
\hline Family & Species & $\mathrm{Ca}^{2+}\left(\mathrm{mmol} \mathrm{l}^{-1}\right)$ & $\mathrm{Na}^{+} \underset{\left.1^{-1}\right)}{(\mathrm{mmol}}$ & $\mathrm{K}^{+}\left(\mathrm{mmol} \mathrm{l}^{-1}\right)$ & $\mathrm{Mg}^{2+}\left(\mathrm{mmol} \mathrm{l}^{-1}\right)$ & $\mathrm{Cl}^{-}\left(\mathrm{mmol} \mathrm{l}^{-1}\right)$ & $\begin{array}{l}\text { References and } \\
\text { comments }\end{array}$ \\
\hline \multirow{5}{*}{ Cyprinidae } & Cyprinids & $0.3-12.5$ & $94-107$ & $39-78$ & $0.02-1.2$ & & {$[64,65]$} \\
\hline & \multirow[t]{2}{*}{ Cyprinus carpio } & $\begin{array}{c}10.69 \pm 2.71^{1} \\
11.54 \pm 0.73^{2} \\
8.74 \pm 2.93^{3}\end{array}$ & $\begin{array}{l}71.25 \pm 3.65^{1} \\
59.00 \pm 3.16^{2} \\
58.12 \pm 5.27^{3}\end{array}$ & $\begin{array}{l}78.87 \pm 3.72^{1} \\
73.01 \pm 3.46^{2} \\
77.56 \pm 4.57^{3}\end{array}$ & & $\begin{array}{c}110.62 \pm 8.81^{1} \\
96.25 \pm 3.58^{2} \\
102.12 \pm 7.25^{3}\end{array}$ & $\begin{array}{c}{[66]} \\
{ }^{1} \text { Winter, }{ }^{2} \text { Early } \\
\text { spring, }{ }^{3} \text { Late } \\
\text { spring }\end{array}$ \\
\hline & & $2 \pm 0.18$ & $75 \pm 3.2$ & $82.4 \pm 3.3$ & $0.8 \pm 0.04$ & & {$[67]$} \\
\hline & $\begin{array}{c}\text { Ctenopharyngodon } \\
\text { idella }\end{array}$ & 1.0 & 81.1 & 35.1 & 1.6 & & [68] \\
\hline & Tinca tinca & $0.60 \pm 0.2$ & $18.40 \pm 1.3$ & $1.93 \pm 0.6$ & $0.45 \pm 0.1$ & & {$[69,70,71]$} \\
\hline \multirow[t]{4}{*}{ Salmonidae } & Salmonids & $0.3-2.6$ & $103-140$ & $20-66$ & $0.8-3.6$ & & {$[64,65]$} \\
\hline & Salmo salar & 1.3 & 103 & 22 & 0.9 & & [72] \\
\hline & \multirow[t]{2}{*}{$\begin{array}{l}\text { Oncorhynchus } \\
\text { mykiss }\end{array}$} & $1.10 \pm 0.26$ & $122 \pm 14.2$ & $30.4 \pm 4.5$ & $0.85 \pm 0.12$ & & [73] \\
\hline & & $1.2 \pm 0.3$ & $159.8 \pm 30.8$ & $25.7 \pm 4.1$ & & & [74] \\
\hline \multirow[t]{2}{*}{ Acipenseridae } & Polyodon spathula & $7.8 \mathrm{mg} \mathrm{l}^{-1}$ & $500 \mathrm{mg} \mathrm{l}^{-1}$ & $97.3 \mathrm{mg} \mathrm{l}^{-1}$ & $55 \mathrm{mg} \mathrm{l}^{-1}$ & & {$[69,70,71]$} \\
\hline & $\begin{array}{l}\text { Acipenser fulvec- } \\
\text { sens }\end{array}$ & $0.16 \pm 0.05$ & $25.6 \pm 2.8$ & $5.78 \pm 0.49$ & $0.21 \pm 0.02$ & $5.41 \pm 2.79$ & {$[75]$} \\
\hline
\end{tabular}




\section{Sperm Motility Characteristics}

Motility is a characteristic function of the male gamete, which allows sperm to actively reach and penetrate the female gamete in organisms with internal and external fertilization. Sperm motility is acquired under the control of many extrinsic and intrinsic factors and is based on the specialized structure of the sperm flagellum. Generally, sperm of fishes spawning in brackish and sea water swim much longer than those of most freshwater species[76]. However, the duration of sperm motility is brief in most fish species and only lasts for $30 \mathrm{sec}$ to few minutes[77].

Sperm of both freshwater and seawater fish are immotile in the male reproductive organ, or in electrolyte or nonelectrolyte solutions having similar osmolality to that of the seminal plasma, but gain potentiality for activation during transfer to the sperm duct. The physiological changes that occur after transfer is controlled by an endocrinological system, which regulate spermatogenesis and spermiation[64, $65,78]$. Seminal plasma produced by the sperm duct provides an ionic environment that maintains the viability of spermatozoa after their release from the testes[79]. It has been already shown in the literature that there are several correlations between seminal plasma composition and sperm motility in some species; Atlantic salmon, Salmo salar[72], common carp, Cyprinus carpio[66], bleak, Alburnus alburnus[74], rainbow trout, Oncorhynchus mykiss[80], Persian sturgeon, Acipenser persicus[81] and chinook salmon, Oncorhynchus tshawytscha[82]. In freshwater species, matured sperm need a hypo-osmotic shock for triggering initiation of sperm motility[29]. Moreover, there are several factors that affect sperm motility such as temperature, $\mathrm{pH}$, ions and osmolality[28, 29, 30, 83].

\subsection{Effect of Temperature}

The motility duration, fertilizing ability and velocity of sperm depend on temperature of the activation medium $[5,65$, $84]$ and of that of the broodstock holding tank[85]. Because the energetic resources of fish sperm are limited, an increase in velocity caused by a temperature rise in the swimming solution leads to a shorter duration of motility, and conversely, lowering the swimming temperature results in a prolonged duration of motility and reduced cell velocity $[5$, 84]. The motility duration of grass carp, Ctenopharyngodon idella sperm is shorter than the common carp[86, 87]. It has been confirmed that sperm are motile for longer at $20^{\circ} \mathrm{C}$ than at 26 or $30^{\circ} \mathrm{C}$ in common carp or $30^{\circ} \mathrm{C}$ in grass carp[87], whereas in Siberian sturgeon, Acipenser baeri, sperm decreases when the temperature is increased from 10 to $17.5^{\circ} \mathrm{C}$ [85].

\subsection{Effect of $\mathrm{pH}$}

It has been shown that extracellular and intracellular $\mathrm{pH}$, as well as the ionic composition of the activating solution, influences the initiation and duration of sperm motility[88]. The external $\mathrm{pH}$ probably influences the intracellular proton concentration, which subsequently affects the membrane potential, as well as motility behavior $[89,90]$. In rainbow trout the $\mathrm{pH}$ of seminal plasma is usually 7.5 to 8.5 . Carp sperm motility can be initiated in media with an external $\mathrm{pH}$ of $6.0-9.0[91,92]$. On the other hand, the internal $\mathrm{pH}$ of the sperm is about 1 unit below the external $\mathrm{pH}[60,93]$.

\subsection{Effect of Ions}

\subsubsection{Potassium $\left(\mathrm{K}^{+}\right)$}

Among the above mentioned factors, $\mathrm{K}^{+}$concentration is a key factor in combination with osmotic pressure that control sperm motility and allow it to be initiated in salmonids [ 49 , 84], sturgeons and paddlefish[53, 62, 67, 69, 70, 71, 81, 94, 95]. It has been known since 1938 that millimolar level of extracellular $\mathrm{K}$ ion concentration $\left(\left[\mathrm{K}^{+}\right]_{0}\right)$ in the seminal tract is primarily responsible for keeping trout sperm inactive[96]. This phenomenon was further investigated by some scientists and they showed that salmonid fish sperm motility can be initiated in $\mathrm{K}^{+}$-free medium, but not in $\mathrm{K}^{+}$-supplemented medium, which is similar to the seminal fluid[16]. This group also showed that cyclic adenosine monophosphate (cAMP) increases and reaches a plateau seconds after suspending trout sperm in $\mathrm{K}^{+}$-free medium[97]. Although $\left[\mathrm{K}^{+}\right]_{\mathrm{o}}$ and cAMP were known to influence motility, their relationship is still unknown. Potassium channel blockers like, Tetraethylammonium $\left(\mathrm{TEA}^{+}\right)$, nonyltriethylammonium1, $\mathrm{Ba}^{2+}$, and $\mathrm{Cs}^{+}$, inhibited sperm motility initiation[98].

The above results obtained on induction of sperm motility suggest the hypothesis: "the inhibition of motility in salmonids is mainly due to $\mathrm{K}^{+}$ion". In other words, membrane hyperpolarization caused directly by transmembrane $\mathrm{K}^{+}$ efflux is the first trigger for initiating sperm motility in salmonid fishes[99].

In cyprinids $\mathrm{K}^{+}$ion also increases sperm velocity and motility and $\mathrm{K}^{+}$channel inhibitors markedly inhibited the flagellar motion[67, 94, 95]. The potent effects of $\mathrm{K}^{+}$ion were investigated in demembranated flagella; axonemal motility was found to be directly controlled by the ion concentration $[69,70,71]$. It is also clear that the $\mathrm{K}^{+}$concentrations in diluents used for cryopreservation strongly influence the potential motility of carp sperm[100].

To date, the mechanism regulating mobility in sturgeon and paddlefish sperm has not been fully identified, but it presents quite striking similarities with that in salmonid sperm. A recent study by Alavi and his group showed that the potassium concentration in Acipenser persicus seminal plasma was $6.92 \pm 0.88 \mathrm{mmol} \mathrm{l}^{-1}[81]$. These findings indicated that seminal plasma $\mathrm{K}^{+}$is a major inhibitor of sperm motility in A. persicus.

\subsubsection{Calcium $\left(\mathrm{Ca}^{2+}\right)$}

Sperm motility can be initiated by alteration of the concentration of $\mathrm{Ca}^{2+}$ ions in many species, such as in cyprinids, extracellular $\mathrm{Ca}^{2+}\left(\left[\mathrm{Ca}^{2+}\right]_{\mathrm{o}}\right)$ is a prerequisite for the initiation of live sperm motility. Krasznai and his group found that sperm motility is initiated after $30 \mathrm{sec}$ when $10^{-4} \mathrm{M} \mathrm{NaCl}$ was added to the swimming solution[95]. Also, when sperm were 
demembranated with Triton X-100, they exhibited high motility in $10^{-6}$ and $10^{-5} \mathrm{M} \mathrm{Ca}^{2+}$. Verapamil, a $\mathrm{Ca}^{2+}$ channel blocker inhibited the motility of mature carp sperm prediluted and incubated in physiological solution $(140 \mathrm{mM} \mathrm{NaCl}$, $10 \mathrm{mM} \mathrm{KCl}, 1 \mathrm{mM} \mathrm{CaCl}_{2}$, and $20 \mathrm{mM}$ HEPES, $\mathrm{pH} 8.5$ ), and completely eliminated the increase in intracellular $\mathrm{Ca}^{2+}$ $\left(\left[\mathrm{Ca}^{2+}\right]_{i}\right)$. They also suggested that influx of $\left[\mathrm{Ca}^{2+}\right]_{0}$ through specific channels leads to induction of $\left[\mathrm{Ca}^{2+}\right]_{i}$ release from stores and initiates sperm motility through the calmodulin system. Except verapamil, several specific $\mathrm{Ca}^{2+}$ channel blockers (eg. flunarizine and the conotoxin family) also prevent the increase of $\left[\mathrm{Ca}^{2+}\right]_{i}$ in the common carp, and the initiation of sperm motility is subsequently suppressed[101]. In tilapia (Oreochromis mossambicus) it was also found that $\left[\mathrm{Ca}^{2+}\right]_{\mathrm{i}}$ is required for activation of sperm motility and can prolong the motility period[102]. The $\mathrm{Ca}^{2+}$-sensitive fluorescent probes have indicated $\left[\mathrm{Ca}^{2+}\right]_{\mathrm{i}}$ increases in single sperm [103] and in sperm populations [90] upon initiation of motility. The contribution of $\left[\mathrm{Ca}^{2+}\right]_{0}$ and internal $\mathrm{Ca}^{2+}$ stores to the $\left[\mathrm{Ca}^{2+}\right]_{\mathrm{i}}$ increase that occurs when motility is initiated still remains to be established. The river water into which sperm are spawned contains $0.3-0.4 \mathrm{mM} \mathrm{Ca}^{2+}$, enough to contribute to $\mathrm{Ca}^{2+}$ influx through specific sperm plasma membrane $\mathrm{Ca}^{2+}$ channels under physiological conditions.

\subsection{Effect of Osmotic Pressure on Sperm Motility}

Exposure to hypo-osmotic or hyperosmotic environment triggers the initiation of fish sperm motility. Sperm of freshwater fish become motile when diluted in a hypotonic solution[16, 67, 88, 104]. Sperm of freshwater Cyprinidae (goldfish, carp, crucian carp and dace) remained immotile when the semen was diluted in solutions of $\mathrm{NaCl}, \mathrm{KCl}$, mannitol or glucose iso-osmolar to the seminal plasma (300 mOsm $\mathrm{kg}^{-1}$ ). The sperm became motile in media containing these solutes if the osmolality was lower than that of the seminal plasma $\left(<200 \mathrm{mOsm} \mathrm{kg}^{-1}\right)$, suggesting that motility is suppressed by the osmolality of the seminal plasma in the sperm duct and initiated by a decrease of osmolality upon spawning into freshwater[67]. Exposure to hyperosmotic seawater also triggers the initiation of sperm motility of marine fish species[16, 105, 106]. Sperm of the marine puffer fish are quiescent in their seminal plasma (around 300 mOsm $\mathrm{kg}^{-1}$ ) and become motile when there is an increase in the osmolality of the surrounding medium (1200 mOsm kg $\left.\mathrm{g}^{-1}\right)$ [105]. This hyperosmotic shock could induce an increase in the $\left[\mathrm{K}^{+}\right]_{i}[106]$ and in the $\mathrm{Ca}^{2+}$ concentration, and an internal acidification[105]. It has been proposed that these series of variations are the trigger for the activation of motility.

For live bearing (internal fertilization) fishes, such as those of the freshwater genus Xiphophorus[107] and the marine ocean pout Macrozoarces americanus[108], sperm motility can be initiated by isotonic osmolalities but not by hypotonic or hypertonic osmolalities. Once initiated, the sperm of these species can remain continuously motile for as long as 1 week[109].

Recently, it was found that sperm motility in a euryhaline fish, medaka (Oryzias latipes) was initiated across a broad range of osmolalities varying from deionized water (25 $\mathrm{mOsm} / \mathrm{kg}$ ) and HBSS (Hanks' balanced salt solution) with hypotonic, isotonic, and hypertonic osmolalities ranging from 92 to $686 \mathrm{mOsm} / \mathrm{kg}[110]$. A euryhaline fish (eg. tilapia), sperm had a similar but attenuated pattern of motility activation. The particular fish studied originated from brackish water and were acclimated to freshwater[102] or seawater[111]. For the freshwater acclimated tilapia, sperm motility could be activated by osmolalities ranging from 0 to $400 \mathrm{mOsm} / \mathrm{kg}$, with or without electrolytes, and $\mathrm{Ca}^{2+}$ was found to be required for motility activation[111]. For the seawater-acclimated tilapia, sperm motility could be activated by osmolalities from 0 to $500 \mathrm{mOsm} / \mathrm{kg}$ of $\mathrm{NaCl}$ with 10 mM HEPES (N-2-Hydroxyethylpiperazone-n-2-Ethanesu Ifonic Acid), and the addition of $\mathrm{Ca}^{2+}$ caused increased motility in the presence of high osmolalities (1000 to 1400 $\mathrm{mOsm} / \mathrm{kg})[111]$.

\section{REFERENCES}

[1] Mattei X (1991). Spermatozoa ultrastructure and its systematic implications in fishes. J Zool 69:3038-3055.

[2] Baccetti B, Burrini AG, Callaini G et al. (1984). Fish germinal cells. I. Comparative spermatology of seven cyprinid species. Gamete Res 10:373-396.

[3] Baccetti B (1986). Evolutionary trends in sperm structure. Comp Biochem Physiol A 85:29-36.

[4] Jones PR and Butler RD (1988). Spermatozoon ultrastructure of Platichthys flesus. J Ultrastruct Mol Struct Res 98:71-82.

[5] Ginsburg AS (1968). Fertilization of fishes and the problem of polyspermy. Translation: NOOAA and National Science Foundation, Academy of Science USSR, Moscow, p 354.

[6] Grier HJ, Fitzsimons JM, Linton JR (1978). Structure and ultrastructure of the testis and sperm formation in goodeid teleosts. J Morphol 156(3):419-37.

[7] Mattei C, Mattei X (1974). Spermiogenesis and spermatozoa of the Eiopomorpha (teleost fish). In: Afzelius BA (ed) The functional anatomy of the spermatozoon. Oxford: Pergamon Press, pp 211-21.

[8] Lahnsteiner F, Patzner RA (1997). Fine structure of spermatozoa of four littoral teleosts Symphodus ocellatus, Corisjulis, Thalassoma pavo and Chromis chromis. J Submicr Cytol Path 29:477-85.

[9] Jamieson BGM (1991). Fish evolution and systematics: evidence from spermatozoa. Cambridge University Press. Cambridge, UK.

[10] Lahnsteiner F, Patzner RA (2007). Sperm morphology and ultrastructure in fish. In: Alavi SMH, Cosson J, Coward K, Rafiee G (eds) Fish spermatology. Oxford: Alpha Science Ltd. pp 1-61. 
[11] Mattei X (1988). The flagellar apparatus of spermatozoa in fish. Ultrastructure and Evolution Biol Cell 63:151-158.

[12] Luo D, Sun JJ, Lu X et al. (2011). Comparative sperm ultrastructure of three species in Siniperca (Teleostei: Perciformes: Sinipercidae) Micron 42:884-891.

[13] Johnson CH, Clapper DL, Winkler MM et al. (1983). A volatile inhibitor immobilizes sea urchin sperm in semen by depressing intracellular $\mathrm{pH}$. Dev Biol 98:493-501.

[14] Christen RW, Schackmann RW, Shapiro BM (1982). Elevation of intracellular $\mathrm{pH}$ activates respiration and motility of sperm of the sea urchin Strongylocentrotus purpuratus. J Biol Chem 257:14881-14890.

[15] Lee, HC, Johnson C, Epel D (1983). Changes in internal pH associated with the initiation of motility and acrosome reaction of sea urchin sperm. Dev Biol 95: 31-45

[16] Morisawa M, Suzuki K (1980). Osmolality and potassium ion: their roles in initiation of sperm motility in teleosts. Science 210:1145-1147.

[17] Perchec G, Cosson J, Andre' F et al. (1993). Spermatozoa motility of trout (Oncorhynchus mykiss) and carp (Cyprinus carpio). J Appl Ichthyol 9:129-149.

[18] Billard R, Cosson J, Crim LW et al. (1995a). Sperm physiology and quality. In: Bromage, N, Roberts R (eds) Broodstock Management and Egg and Larval Quality. Blackwell, Oxford, pp 25-52.

[19] Kime DE, Van Look KJW, McAllister BG et al. (2001). Computer assisted sperm analysis (CASA) as a tool for monitoring sperm quality in fish. Comp Biochem Physiol 130:425- 433 .

[20] Kime DE, Tveiten H (2002). Unusual motility characteristics of sperm of the spotted wolffish. J Fish Biol 61:1549-1559.

[21] Elofsson H, McAllister BG, Kime DE et al. (2003a). Long lasting sticklebacks sperm; is ovarian fluid a key to success in freshwater? J Fish Biol 63:240-253.

[22] Elofsson H, Van Look K, Borg B et al. (2003b). Influence of salinity and ovarian fluid on sperm motility in the fifteen spine stickleback. J Fish Biol 63:1429-1438.

[23] Lahnsteiner F (2011). Spermatozoa of the teleost fish Perca fluviatilis (perch) have the ability to swim for more than two hours in saline solutions. Aquaculture 314: 221-224.

[24] Lahnsteiner F and Patzner RA (2008). Sperm morphology and ultrastructure in fish. In: Alavi SMH, Cosson J,Coward K, Rafiee G (eds) Fish Spermatology. Alpha Science Ltd, Oxford, UK, pp 1-62.

[25] Alavi SMH, Cosson J (2005b). Sperm motility and fertilizing ability in the Persian sturgeon Acipenser persicus. Aquacult Res 36:841-850.

[26] Vladic TV, Afzelius BA, Bronnikov GE (2002). Sperm quality as reflected through morphology in salmon alternative life histories. Biol Reprod 66:98-105.

[27] Gage MJG, MacFarlane CP, Yeates S et al. (2004). Spermatozoal traits and sperm competition in Atlantic salmon: relative sperm velocity is the primary determinant of fertilization success. Curr Biol 14:44-47.

[28] Cosson J, Billard R, Cibert C et al. (1999). Ionic factors regulating the motility of fish sperm. In: Gagnon C (ed) he male gamete: From basic to clinical applications. Cache Rive Press, Vienna, IL, pp 161-186.

[29] Morisawa M, Oda S, Yoshida M et al. (1999) Transmembrane signal transduction for the regulation of sperm motility in fishes and ascidians. In: Gagnon C (ed) The male gamete: From basic to clinical applications. Cache Rive Press, Vienna, IL, pp 149-160.

[30] Alavi SMH, Cosson J (2006). Sperm motility in fishes. (II) Effects of ions and osmolality: a review. Cell Biol Int $30(1): 1-14$

[31] Gibbons BH, Gibbons IR, Baccetti B (1983). Structure and motility of the 9+0 flagellum of eel spermatozoa. J Submicr Cytol Path 15:15-21.

[32] Cherr GN, Clark WN (1984). Acrosome reactions in sperm from the white sturgeon, Acipenser transmontanus. J Exp Zool 232:129-139.

[33] Xu Y, Xiong Q (1988). The process of fertilization of Acipenser sinensis Grey observed by SEM. Acta Zool Sin 34:325-328.

[34] DiLauro MN, Kaboord W, Walsh RA (1998). Sperm-cell ultrastructure of North American sturgeons. I. The Atlantic sturgeon (Acipenser oxyrhynchus). Can J Zool 76:1822-1836.

[35] DiLauro MN, Kaboord WS, Walsh RA (1999). Sperm-cell ultrastructure of North American sturgeons. II. The shortnose sturgeon (Acipenser brevirostrum, Lesueur, 1818). Can J Zool 77:321-330.

[36] DiLauro MN, Kaboord WS, Walsh RA (2000). Sperm-cell ultrastructure of North American sturgeon. I. The Atlantic sturgeon (Acipenser oxyrhynchus). Can J Zool 78:438-447.

[37] DiLauro MN, Walsh RA, Peiffer M (2001). Sperm-cell ultrastructure of North American sturgeons. IV. The pallid sturgeon (Scaphirhynchus albus) Forbes and Richardson, 1905. Can J Zool 79:802-808.

[38] Afzelius BA (1978). Fine structure of the garfish spermatozoan. J Ultrastruct Res 64:309-314.

[39] Ro“heli A, Roth H, Medem F (1950). Elektronoptische Untersuchungen der Struhturveranderung agglutinierter Fishcpermienen. Exp Cell Res 1:115-126.

[40] Mattei X (1969). Spermiogenese comparee' des poissons. In: Baccetti B (ed) Comparative spermatology. Academic Press, New York, pp 57-69.

[41] Billard R (1970). Ultrastructure compare'e de spermatozoides de quelquest poissons te'le'oste'ens. In: Baccetti B (ed) Spermatologia Comparata, vol 137. Quaderno, p 71-80.

[42] Emaljanova NG, Makeeva AP (1985). Ultrastructure of spermatozoids of some cyprinid fishes (Cyprinidae). J Appl Ichthyol 25:137-144.

[43] Lahnsteiner F (2003). The spermatozoa and eggs of the cardinal fish. J Fish Biol 62:115-128.

[44] Todd PR (1976). Ultrastructure of the spermatozoa and spermiogenesis in New Zealand freshwater eels (Anquillidae). Cell Tissue Res 171:221-232.

[45] Gibbons BH, Baccetti B, Gibbons IR (1985). Live and reac- 
tivated motility in the $9+0$ flagellum of anquilla sperm. Cell Motil 5:333-351.

[46] Pecio A, Rafinski J (1994). Structure of the testes, spermatozoa and spermatozeugmata of Mimagoniates-barberi (Regan), (teleostei. characidae), and internally fertilizing, oviparous fish. Acta Zool 75:179-185.

[47] Okamura A, Motonobu T (1999). Spermatozoa of Conger myriaster observed by electron microscopy. Zool Sci 16:927-933.

[48] Retzius G (1906). Die Spermie der Leptokardier, Teleostier, und Ganoiden. Biol Untersuchungen g Retzius 12:103-115.

[49] Billard R (1983). Ultrastructure of trout spermatozoa: changes after dilution and deep freezing. Cell Tissue Res 228:205-218.

[50] Lowman FG (1953). Electron microscope studies of silver salmon spermatozoa (Oncorhynchus kisutch W.). Exp Cell Res 5:335-360.

[51] Jaspers EJ, Avault JW, Roussel JD (1976). Spermatozoal morphology and ultrastructure of channel catfish, Ictalarus punctatus. Tam Fish Soc 150:475-480.

[52] Stanley HP (1969). An electron microscope study of spermiogenesis in the teleost fish Oligocottus moculosus. J Ultrastruct Res 27:230-243.

[53] Ciereszko A, Glogowski J, Dabrowski K (2000). Biochemical characteristics of seminal plasma and spermatozoa of fresh water fishes. In: Tiersch TR, Mazik PM (eds) Cryopreservation in aquatic species. Louisiana,WAS, Baton Rouge, pp 20-48

[54] Linhart O, Slechta V, Slavik T (1991). Fish sperm composition and biochemistry. Bull Inst Zool Acad Sin Monogr $16: 285-311$

[55] Coward K, Bromage NR, Hibbitt O et al. (2002). Gametogenesis, fertilization and egg activation in teleost fish. Rev Fish Biol Fish 12:33-58.

[56] Ingermann R, Holcomb M, Robinson ML et al. (2002). Carbon dioxide and $\mathrm{pH}$ affect sperm motility of white sturgeon (Acipenser transmontanus). J Exp Biol 205:2885-2890.

[57] Itoh A, Inaba K, Ohtake H et al. (2003). Characterization of a cAMP-dependent protein kinase catalytic subunit from rainbow trout spermatozoa.Biochem Biophys Res Commun 305:855-861.

[58] Kowalski R, Wojtczak M, Glogowski J et al. (2003). Gelatinolytic and antitrypsin activities in seminal plasma of common carp: relationship to blood, skin mucus and spermatozoa. Aquat Living Resour 16:438-444.

[59] Wojtczak M, Glogowski J, Koldras M et al. (2003). Characterization of protease inhibitors of seminal plasma of cyprinids. Aquat Living Resour 16:461-465.

[60] Billard R (1986). Spermatogenesis and spermatology of some teleost fish species. Reprod Nutr Dev 2:877-920.

[61] Rurangwa E, Kime DE, Ollevier F et al. (2004). Measurement of sperm motility and factors affecting sperm quality in cultured fish. Aquaculture 234:1-28.

[62] Alavi SMH, Cosson J (2005a). Sperm motility in fishes: (I) effects of temperature and $\mathrm{pH}$. Cell Biol Int 29:101-110.
[63] Piros B, Glogowski J, Kolman R et al. (2002). Biochemical characterization of Siberian sturgeon Acipenser baeri and starlet, Acipenser ruthenus, milt plasma and spermatozoa. Fish Physiol Biochem 26:289-295.

[64] Billard R, Cosson J, Crim LW et al. (1995a). Sperm physiology and quality. In: Bromage, N, Roberts R (eds) Broodstock Management and Egg and Larval Quality. Blackwell, Oxford, pp 25- 52.

[65] Billard R, Cosson J, Perchec G et al. (1995b). Biology of sperm and artificial reproduction in carp. Aquaculture 124:95-112.

[66] Kruger JC, Smith GL, Van Vuren JHJ et al. (1984). Some chemical and physical characteristics of the semen of $C y$ prinus carpio and Oreochromis mossambicus. J Fish Biol 24: 263-272.

[67] Morisawa M, Suzuki K, Shimizu H (1983). Effect of osmolality and potassium on motility of spermatozoa from freshwater cyprinid fishes. J Exp Biol 107:95-103.

[68] Gosh RI (1985). Energeticeskij obmen polovych kletok I embrionoy u ryb Kiev. Naukova Dumka p. 147 (in Russian).

[69] Linhart O, Cosson J, Mims SD (2003a). Effects of ions on the motility of fresh and demembranated sperm of common carp (Cyprinus carpio) and paddlefish (Polyodon spathula). Fish Physiol Biochem 28:203-205.

[70] Linhart O, Mims SD, Boris GB (2003b). Ionic composition and osmolality of paddlefish (Polyodon spathula, Acipenseriformes) seminal fluid. Aquacult Int 11:357-368.

[71] Linhart O, Rodina M, Bastl J et al. (2003c). Urinary bladder, ionic composition of seminal fluid and urine with characterization of sperm motility in tench (Tinca tinca L.). J Appl Ichthyol 19:177-181.

[72] Hwang PC, Idler DR (1969). A study of major cations, osmotic pressure, and $\mathrm{pH}$ in seminal components of Atlantic salmon. J Fish Res Board Can 26:413-419.

[73] Glogowski J, Kwasnik M, Iros B et al. (2000). Characterization of rainbow trout milt collected with a catheter: semen parameters and cryopreservation successes. Aquat Res 31: 289-296.

[74] Lahnsteiner F, Berger B, Weismann T et al. (1996). Motility of spermatozoa of Alburnus alburnus (Cyprinidae) and its relationship to seminal plasma composition and sperm metabolism. Fish Physiol Biochem 15:167-179.

[75] Toth GP, Ciereszko A, Christ SA et al. (1997). Objective analysis of sperm motility in the Lake sturgeon, Acipenser fulvescens: activation and inhibition conditions. Aquaculture 154:337-348

[76] Ginsburg AS (1963). Sperm-egg association and its relationship to the activation of the egg in salmonid fishes. $J$ Embr Exp Morpho 11:13-33.

[77] Billard R, Cosson J, Crim LW (1993). Motility of fresh and aged halibut sperm. Aquat Living Resour 6:67-75.

[78] Nagahama Y (1994). Endocrine regulation of gametogenesis in fish. Int J Dev Biol 38:217-29.

[79] Ciereszko A (2008). Chemical composition of seminal plasma and its physiological relationship with sperm motility, fertilizing capacity and cryopreservation success in fish. In: 
Alavi SMH, Cosson J, Coward R, Rafiee G (eds) Fish Spermatology. Alpha Science Ltd, Oxford, pp 215-240.

[80] Lahnsteiner F, Berger B, Weismann T et al. (1998). Determination of semen quality of the rainbow trout by sperm motility, seminal plasma parameters and spermatozoal metabolism. Aquaculture 163:163-181.

[81] Alavi SMH, Cosson J, Karami M et al. (2004). Chemical composition and osmolality of seminal fluid of Acipenser persicus; their hysiological relationship with sperm motility. Aquac Res 35:1238-1243.

[82] Rosengrave P, Taylor H, Montgomerie R et al. (2009). Chemical composition of seminal and ovarian fluids of Chinook salmon (Oncorhynchus tshawytscha) and their effects on spermmotility traits. Comp Biochem Physiol A 152:123-129.

[83] Alavi SMH, Gela D, Rodina M et al. (2011). Roles of osmolality, calcium - Potassium antagonist and calcium in activation and flagellar beating pattern of sturgeon sperm Comp Biochem Physiol - Part A: 160:166-174.

[84] Stoss J (1983). Fish gamete preservation and spermatozoan physiology. In: Hoar WS, Randall DJ, Donaldson EM (eds) Fish physiology 1X B. Academic Press, New York, pp 305-350.

[85] Williot P, Kopeika EF, Goncharov BF (2000). Influence of testis state, temperature and delay in semen collection on spermatozoa motility in the cultured Siberian sturgeon (Acipenser baeri Brandt). Aquaculture 189:53-61.

[86] Belova NV (1981). Ecological and physiological characteristics of sperm of pond Cyprinid fishes. Vopr Ichtiol 21:525-536 (in Russian).

[87] Jezierska B, Witeska M (1999). The effect of time and temperature on motility of spermatozoa of common and grass carp. Elec J Polish Agricult Univers 2:1-8. !

http://www.ejpau.media.pl/series/volume2/issue2/fisheries/ar $\mathrm{t}-04 . \mathrm{html}$.

[88] Ma'ria'n T, Krasznai Z, Balkay L et al. (1997). Role of extra-and intracellular $\mathrm{pH}$ in the sperm motility. Hyperosmosis modifies regulation of the $\mathrm{Na}^{+} / \mathrm{H}^{+}$exchanger in the carp sperm. Cytometry 27:374-382.

[89] Boitano S, Omoto CK (1991). Membrane hyperpolarization activates trout sperm without an increase in intracellular $\mathrm{pH}$. J Cell Sci 98:343-349.

[90] Boitano S, Omoto CK (1992). Trout sperm swimming patterns and role of intracellular $\mathrm{Ca}^{2+}$ Cell Motil Cytoskeleton $21: 74-82$

[91] Redondo-Muller C, Cosson MP, Cosson J et al. (1991). In vitro maturation of the potential for movement of carp spermatozoa. Mol Reprod Dev 29:259-270.

[92] Perchec-Poupard G, Gatti JL, Cosson J et al. (1997). Effects of extracelular environment on the osmotic signal transduction involved in activation of motility of carp spermatozoa. J Reprod Fertil 110:315-327.

[93] Gatti JL, Billard R, Christen R (1990). Ionic regulation of the plasma membrane potential of rainbow trout (Salmo gairdneri) sperm: role in the initiation of motility. J Cell Physiol 143:546-554.

[94] Krasznai Z, Marian T, Balkay L et al. (1995). Potassium channels regulate hypo-osmotic shock-induced motility of Common Carp, Cyprinus carpio, sperm. Aquaculture 129:123-128

[95] Krasznai Z, Marian T, Izumi H et al. (2000). Membrane hyper polarization removes inactivation of $\mathrm{Ca}^{2+}$ channels leading to $\mathrm{Ca}^{2+}$ influx and initiation of sperm motility in the common carp. Biophysics 97:2052-2067.

[96] Schlenk W, Kahmann H (1938). The chemical composition of seminal fluids and their physiological importance study with trout sperm. Biochem Zool 295:283-301.

[97] Morisawa M, Ishida K (1987). Short-term changes in levels of cyclic AMP, adenylate cyclase, and phosphodiesterase during the initiation of sperm motility in rainbow trout. $\mathrm{J}$ Exp Zool 242:199-204.

[98] Tanimoto S, Morisawa M (1988). Roles for potassium and calcium channels in the initiation of sperm motility in rainbow trout. Dev Growth Differ 30:117-124.

[99] Kho KH, Tanimoto S, Inaba K et al. (2001). Transmembrane cell signaling for the initiation of trout sperm motility: roles of ion channels and membrane hyperpolarization for cyclic AMP synthesis. Zool Sci 18:919-928.

[100] Linhart O, Cosson J (1997). Cryopreservation of Carp (Cyprinus carpio L.) spermatozoa: the influence of external $\mathrm{K}^{+}$ and $\mathrm{Na}^{+}$on post-thaw motility. Pol Arch Hydrobiol 44(1\&2):273-277.

[101] Krasznai Z, Morisawa M, Morisawa S (2003). Role of ion channels and membrane potential in the initiation of carp sperm motility. Aquat Living Resour 16:445-449.

[102] Morita M, Takemura A, Okuno M (2003). Requirement of $\mathrm{Ca}^{2+}$ on activation of sperm motility in euryhaline tilapia Oreochromis mossambicus. J Exp Biol 206:913-921.

[103] Tanimoto S, Kudo Y, Nakazawa T et al (1994). Implication that potassium flux and increase in intracellular calcium are necessary for the initiation of sperm motility in salmonid fishes. Mol Reprod Dev 39:409-414.

[104] Ma'ria'n T, Krasznai Z, Balkay L et al. (1993). Hypo-osmotic shock induces an osmolality-dependent permeabilization and structural changes in the membrane of carp sperm. Histochem Cytochem 41:291-297.

[105] Oda S, Morisawa M (1993). Rises of intracellular $\mathrm{Ca}^{2+}$ and $\mathrm{pH}$ mediate the initiation of sperm motility by hyperosmolality in marine teleosts. Cell Moti Cytos 25:171-178.

[106] Takai H, Morisawa M (1995). Change in intracellular $\mathrm{K}^{+}$ concentration caused by external osmolality change regulates sperm motility of marine and freshwater teleosts. J Cell Sci 108:1175-1181.

[107] Yang H, Hazelwood L,Walter RB et al. (2006). Effect of osmotic immobilization on refrigerated storage and cryopreservation of sperm from a viviparous fish, the green swordtail Xiphophorus helleri. Cryobiology 52:209-218.

[108] Yao Z, Crim LW, Richardson GF et al. (2000). Motility, fertility and ultrastructural changes of ocean pout Macrozoarces americanus L. sperm after cryopreservation. Aquaculture 181:361-375.

[109] Huang C, Dong Q, Walter RB et al. (2004). Initial studies on sperm cryopreservation of a live-bearing fish, the green swordtail Xiphophorus helleri. Theriogenology 62:179-194. 
[110] Yang H, Tiersch TR (2009). Sperm motility initiation and duration in a euryhaline fish, medaka (Oryzias latipes). Theriogenology 72:386-392.

[111] Morita M, Takemura A, Okuno M (2004). Acclimation of sperm motility apparatus in seawater-acclimated euryhaline tilapia Oreochromis mossambicus. J Exp Biol 207:337-345.
[112] Islam M Sadiqul (2006). Acrosome reaction in marine animals: gateway to sperm fusion with the egg. Asian J Cell Biol 1:14-28.

[113] Psenicka M, Rodina M, Nebesarova J et al. (2006). Ultrastructure of spermatozoa of tench Tinca tinca observed by means of scanning and transmission electron microscopy. Theriogenology 66:1355-1363. 